\title{
Review
}

\section{Strangers in our midst: The political philosophy of immigration}

\author{
David Miller \\ Harvard University Press, 2016, 218pp., ISBN: 9780674088900
}

Contemporary Political Theory (2018) 17, S240-S243. https://doi.org/10.1057/s41296017-0147-6; published online 12 September 2017

Well-reasoned reflection on the challenges that immigration raises has immediate practical importance given the breadth of issues in play, the global scope of immigration, the contentious policy debates that dominate the political landscape, and the consequences such policies have for the well-being and identities of masses of people. David Miller's political philosophy of immigration provides an accessible, informed, and thoroughgoing defence of immigration control by liberal democratic states, guided by values of weak cosmopolitanism, national self-determination, fairness, and social integration. The 'strangers in our midst' are immigrants and refugees that do not yet, and may or may not get to, officially join the country by being permitted to enter our political community and share in our national identity.

Compatriot partiality involves commitment to the myth-laden character of national identity, resting on associative obligations we have to fellow citizens in light of our shared relationship. Miller suggests the deep sense of emotional attachment, social bond, and shared experience that features in a strong nation-state tends toward more egalitarian forms of social justice. The considerable identity-defining value modern states generally, and nation-states especially, construct, gives rise to associative obligations and compatriot partiality to protect that value. As members of such states we have reciprocal duties to maintain just political workings through state institutions. This claim assumes that justice promoting, identity conferring, value generating, nation-state based political narratives, structures, and processes exist and should be promoted. As such, we are obligated to ensure their effectiveness by pursuing rights-based principles of justice through the lens of nation-states. Yet if equality among citizens is the primary principle of justice governing relations among domestic citizens and something like global citizenship is acknowledged to be, or is becoming, a basic mode of association, a certain methodological pluralism lends itself to hope for open borders and global justice as increasingly transnational or global forms of identity and solidarity effectively develop.

Miller claims that legitimate political authority is one that fosters an intrinsically valuable form of association by enabling compatriots to coexist on terms of justice,

(C) 2017 Macmillan Publishers Ltd. 1470-8914 Contemporary Political Theory Vol. 17, S4, S240-S243 
and to exercise some degree of control over the direction of this association. Actual states may also exhibit compatriot partiality, given both the moral duties arising from shared citizenship that permit 'us' to do less for non-citizens, along with the constructed mythology of national identity that warrants immigration control. National identity must supply the justification for compatriot partiality. Yet, compatriot partiality is part of the modus operandi of a modern state, not of an individual moral agent. Against the more cosmopolitan view that the value of national identity is instrumental and contingent, neither a necessary part of one's identity nor a requirement for justice, Miller runs duties of justice tightly together with the political obligations of citizens to actively engage and strengthen state institutions.

Although states may close their borders to those wishing to enter, reasons for seeking entry must be seriously considered, including both the basis and extent of the claim. States have more stringent obligations, including a duty of care arising from the vulnerability of the claimant, toward refugees whose human rights are being violated, or who are under sufficiently severe threat, through state persecution, state incapacity, or prolonged natural disasters, that they cannot avoid without migrating. Miller maps out alternative proposals for states to manage the distribution of refugees. Grounds for selection include the need for permanent settlement, any causal role played by the host state in creating the escaped situation, potential economic contributions, and degrees of cultural affinity relevant to the host political community. Provided all claimants are treated equally during their assessment, their human rights are respected, and earnest attempts are made to oversee refugee flows in a fair manner with the international community, Miller contends that states may employ publicly justifiable grounds to set immigration targets, including the number of refugees it admits. While states institute preferences, as a matter of practice, based on shared identities and cultural resemblances, Miller argues they cannot typically prevent refugees from arriving or being admitted, while accepting 'desirable' immigrants, without hypocrisy. Unjustified cultural selection, combined with the absence of a fair system of burden sharing, contributes to a gap between the rights of refugees and the obligations of states to protect such vulnerable migrants.

Miller draws an overly tidy distinction between refugees and economic migrants, designating the latter as motivated to move in order to improve their lives but unable to cite a threat to their human rights as grounds for admission. According to admission records and common practice, migration on narrowly economic grounds is the most available and widespread. Philosophers such as Elizabeth Ashford and Thomas Pogge have argued that severe poverty and disadvantage, involving avoidable institutionally imposed deprivation, violates human rights to subsistence, generating duties to redesign the international order and compensate the poor for deprivation. Liberal democracies, and their wealthy citizens greatly advantaged by the prevailing order, do not typically accept responsibility for global poverty. Immigration policy for economic migrants is thus informed by humanitarian duties, which we have good reason to perform, rather than rights-based duties of justice. Insisting that economic migrants

(c) 2017 Macmillan Publishers Ltd. 1470-8914 Contemporary Political Theory Vol. 17, S4, S240-S243 S241 
cannot claim admission as a matter of justice, even if we sidestep very sticky questions about how and why poverty has arisen, reinforces the view that world poverty is somehow regrettable yet natural rather than a grave and systemic injustice. It also means immigration policy need not directly acknowledge, confront, or aim to mitigate world poverty by ensuring that the social and economic rights of the global poor are protected, including human rights to free movement, subsistence, adequate health care, housing, support in old age, safe working conditions, security against exploitation, and the like. Miller insists that responsibility for safeguarding such rights falls first on the societies that claimants are members of, and then upon the receiving society, by virtue of, and only so long as, the migrants maintain presence on the receiving society's territory. Critics of nationalist state-centric accounts like Miller's contend that such immigration policy risks neutralizing rights-violating global economic forces.

Acceptable reasons for selection or refusal must be consistent, respectful, and not discriminate on grounds that are irrelevant to admission. Miller argues that the creation of human rights shortfalls generated by purposely targeting educated professionals for acceptance, exploiting their skills so expensively acquired elsewhere, are relevant reasons for barring entry. When skills such as medical training are in short supply in their country of origin, and no compensation for such brain drain exists, professionals should be disqualified since there is no general right to immigrate.

Crossing borders illegally is a criminal offence, but being present in a country without authorization is not, in itself, a criminal offence. However, the standing of those without authorization is predictably reduced, making such migrants more vulnerable to exploitation and rights abuse. According to Miller, the logic of territorial jurisdiction means that states must protect the human rights of all those present, whether enlisted members of the political community or not. Length of residence, degree of social membership, and norms of reciprocity inform the extent to which contributing members are entitled to be beneficiaries of a society's practices of social justice. This means that democratic states must ensure that the protection of basic rights is separated from the enforcement of immigration law, allowing that citizenship may be earned so immigrants can advance toward fullmembership, instead of maintaining a permanent caste-divide between citizens and strangers. Integrating immigrants connects to social justice, including equal access to education, employment, health care, and the like, and to peaceful coexistence through understanding, communication, trust, and respect. Provided policies wish to help support social, civic, and cultural integration, without placing demands on individuals that violate their reasonable preferences or offend free pursuit of their own identities, traditions, and beliefs, social bonds can be created to enable an inclusive, multicultural, democratic state to function effectively.

Miller's communitarian model is insufficiently critical of our state-based international order, including tensions between rights-based demands of justice and contingent political institutions. This is a relevant worry and fair general criticism 
given the centrality of states to issues of immigration. It is a dangerous and worrisome line, akin to playing with fire, and what Veit Bader (2005, p. 92) calls 'a foolish recipe' in Miller's work. Miller is right to eschew idealized approaches that risk evading tough choices about what should actually be done, yet his own defence of rights-based immigration control rests upon and tends to reinforce state-centric international order as ideal. We should not be naïve about how we can resolve current, practical problems, but nor should we dismiss or ignore the extent to which existing states grossly fail to live up to the ideal Miller presents. One danger is that we sidestep a more systemic analysis of the state-based international order so often deeply implicated in issues of global justice, including immigration. Another danger is that we turn membership rights into political instruments against reasonable demands of cosmopolitan justice. A familiar historical truism is that it has been easier to disregard the rights of outsiders, including those characteristically represented as strangers and others, than it is fellow members of a shared community, identity, and narrative. Protection of the political community of nation-states is regularly offered as a legitimate reason to limit the rights and opportunities of others. Cosmopolitan values of compassion, human rights, and solidarity between otherwise culturally diverse individuals and peoples seem so often in tension with uniform and mythologized state-centric national identities. Absent from Miller's otherwise highly informed political philosophy of immigration is a critical focus on these dynamics of the international order that appear generative of so many contentious issues of immigration.

Miller provides a range of sensible rights-based arguments meant to inform immigration policy for democratic states. Though working within, and consistently defensive of, our state-based international order, Miller insists that refugee claims be given priority requiring a significant shift in policy. A great strength of this timely book is the practical relevance it has for so many pressing questions. It is helpful in trying to understand, critically engage, and improve immigration policy in liberal democracies. It also serves as a model of thoughtful, well-written political philosophy by an influential political thinker at the top of his game.

\section{Reference}

Bader, V. (2005). Reasonable impartiality and priority for compatriots: A criticism of liberal nationalism's main flaws. Ethical Theory and Moral Practice, 8(1-2), 83-103.

Jeffrey Spring

St. Francis Xavier University, Antigonish, NS B2G 2W5, Canada jspring@stfx.ca 